\title{
Aqueous Fraction of Ocimum gratissimum (L) Leaf Extract Protects Sperm Membrane Integrity in Plumbagin-induced Testicular Damage in Rats
}

\author{
Aanuoluwa James Salemcity ${ }^{1, *}$, Temitope Sekinat Agbaje ${ }^{1}$, Magdalene Eno Effiong ${ }^{2}$, Steve Osagie Asuelimen ${ }^{3}$
}

\section{Aanuoluwa James Salemcity ${ }^{1, *}$, Temitope Sekinat Agbaje', Magdalene Eno Effiong ${ }^{2}$, Steve Osagie Asuelimen ${ }^{3}$}

'Department of Biochemistry, University of Medical Sciences, Ondo, Ondo State, NIGERIA.

2Department of Biochemistry, University of Ibadan, Ibadan, Oyo State, NIGERIA.

${ }^{3}$ Department of Biochemistry, Federal University, Wukari, Taraba State, NIGERIA.

\section{Correspondence}

\section{Dr. Aanuoluwa James Salemcity}

Department of Biochemistry, University of Medical Sciences, Ondo, Ondo State, NIGERIA.

E-mail: xityglory@gmail.com

History

- Submission Date: 09-11-2021:

- Review completed: 23-11-2021;

- Accepted Date: 13-12-2021.

DOI : 10.5530/fra.2021.2.12

Article Available online

http://www.antiox.org

Copyright

(c) 2021 Phcog.Net. This is an openaccess article distributed under the terms of the Creative Commons Attribution 4.0 International license.

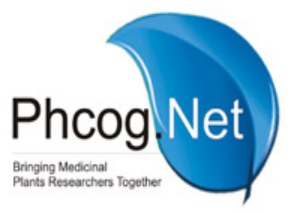

\begin{abstract}
Background: Infertility in male has been associated with oxidative stress which cause membrane damage. The presence of a wide array of secondary metabolites with enormous antioxidant potentials have resulted in the increased medicinal value placed on plants for treatment of various ailments. Ocimum gratissimum is a widely consumed herb well known for its nutritional and medicinal significance. Nevertheless, there is scarcity of information on the impact of Ocimum gratissimum on plumbagin-stimulated male reproductive dysfunction. Therefore this study was designed to determine the effect of aqueous fraction of Ocimum gratissimum (AFOG) leaf extract on sperm plasma membrane integrity and antioxidant status in plumbagin-induced infertility in male wistar rats. Methods: Twenty animals were divided into four equal groups: normal control, $8 \mathrm{mg} / \mathrm{kg}$ plumbagin, groups administered Plumbagin and treated with $100 \mathrm{mg} / \mathrm{kg}$ and $400 \mathrm{mg} / \mathrm{kg}$ AFOG leaf by gavaging for 14 days. Results: The AFOG $(100 \mathrm{mg} / \mathrm{kg}$ and $400 \mathrm{mg} / \mathrm{kg})$ significantly $(P<0.05)$ prevented plumbagin-mediated increase in lipid peroxidation but increased antioxidant parameters [such as glutathione reduced (GSH) levels and the activities of antioxidant enzymes (SOD and CAT)] in a dose-dependent manner. Furthermore, AFOG significantly reversed decrease in testosterone and estradiol levels in plumbagin-induced sterility in male rats and this was corroborated by a significant improvement in sperm features and testes histo-architectures of the co-treated animals. Conclusion: It could therefore be inferred from the above data that Ocimum gratissimum exhibited its cytoprotective role in male reproductive dysfunction via prevention of oxidative stress and maintenance of membrane stability.
\end{abstract}

Key words: Plumbagin, Sterility, Antioxidants, Ocimum gratissimum, Membrane integrity.

\section{INTRODUCTION}

Infertility, a highly prevalent and wide spread public health problem with numerous difficulties inherent in its management, ${ }^{1}$ is associated with the inability to get pregnant after regular sexual activity for a minimum of 12 months without the use of contraception. ${ }^{2}$ It occurs in both male and females with a wide range of causative factors. ${ }^{3}$

Human exposure to numerous environmental contaminants, poor nutrition, underlying health conditions, genetic influence amongst others have largely contributed to increased infertility rates, impaired spermatogenesis, testicular impairments amongst other reproductive health problems. ${ }^{4}$ Oxidative stress resulting from overwhelming generation of oxidants has been linked to etiopathogenesis of male infertility. The mechanism underlying this at times stems from the peroxidation of membrane lipids by the free radicals which leads to membrane damage and invariably apoptosis in spermatogenic cells and thus could alter spermatogenesis and steroidogenesis which are essential for fertility. ${ }^{4}$

Clomiphene citrate among others is employed for the treatment of male infertility as it boosts the levels of luteinizing and follicle-stimulating hormones which impacts on the sperm count. This medication has sometimes been associated with side effects such as vision impairment, exacerbation of prostate cancer if present, and irritability. ${ }^{5}$ The setback with the use of orthodox medicine for the treatment of male sterility makes plant products auxiliary substitute. The use of plants for the treatment of various disease conditions and ailments dates back to human history and constitutes the birth of modern medicine. ${ }^{6}$ They have played a pivotal role as a vital source of active ingredients which serves as templates for the production of drugs to combat diseases and for nutritional purposes. Studies have shown that myriads of medicinal plants possess antioxidant efficacies which are responsible for their use in treating diseases.?

Cite this article: Salemcity AJ, Agbaje TS, Effiong ME, Asuelimen SO. Aqueous Fraction of Ocimum gratissimum (L) Leaf Extract Protects Sperm Membrane Integrity in Plumbagin-induced Testicular Damage in Rats. Free Radicals and Antioxidants. 2021;11(2):52-7. 
Ocimum gratissimum possesses both nutritional and medicinal properties. ${ }^{8}$ It is widely consumed in Nigeria and used severally in the treatment of numerous diseases. ${ }^{9}$ It belongs to the Lamiceae family found mostly in the tropics and sub-tropics. In Nigeria, it is known as nchuanwu by the Igbos, efinrin by the Yorubas and nton by the Efiks. ${ }^{9}$ The leaves of the plant are mostly used in the treatment of catarrh, cold, fever, babies' umbilical cord dressing and fungal infections. ${ }^{10}$

However, there is dearth of information on the influence of Ocimum gratissimum leaf extract on infertility in male rats. Therefore, this study was designed to investigate whether AFOG leaf extract contains bioactive principle that can ameliorate sperm cell membrane damage and prevent infertility induced by Plumbagin in male Wistar rats.

\section{MATERIALS AND METHODS}

\section{Chemicals and Solvents Used}

The research was carried out using analytical graded chemicals of purest quality known. They include methanol, chloroform, n-hexane, ethyl acetate.

\section{Collection of Plant Materials}

The leaves of Ocimum gratissimum were obtained at Iya-Laje Market, Ondo town, Ondo State, Nigeria and authenticated at the department of Pharmacognosy, University of Ibadan, Ibadan, Oyo State, Nigeria with voucher specimen number DPUI 1504. The research was approved by University of Medical Sciences, Ethical Committee, Ondo State, Nigeria with code number UNIMED-EC/20/006.

\section{Preparation of Extract}

The leaves were washed, air-dried and pulverized using blender. Thereafter, the pulverized leaves were soaked in 100\% methanol for $48 \mathrm{hr}$ and the filtrate was obtained using muslin cloth and repeated for four times. The filtrate was concentrated using water bath. The crude extract was then fractionated successively with solvents of increasing polarity between hexane, chloroform ethyl acetate and water via a separating funnel in order to obtain various fractions.

\section{Methods}

\section{Experimental Animals}

The experimental animals used for this study were locally bred male Wistar rats gotten from Ogbomosho, Oyo State, Nigeria. The animals were kept in ventilated cages at the University of Medical Sciences, Ondo State animal house. The animals were acclimatized for one week and maintained under standard environmental conditions and were given feed and water freely. Thereafter they were intubated with $8 \mathrm{mg} / \mathrm{kg}$ of plumbagin for two weeks and then treated with doses AFOG for 14 days. The animals were handled in compliance with the University of Medical Sciences, Ondo, Ondo State, Nigeria, ethical committee and animal use.

\section{Experimental Design}

Twenty rats, acclimatized for 7 days, weighing from $80 \mathrm{~g}$ to $100 \mathrm{~g}$ were utilized. These were randomly distributed into four equal groups in aerated cages and administered $8 \mathrm{mg} / \mathrm{kg}$ Plumbagin (p.o) for 14 days. ${ }^{11}$ Thereafter, they were orally treated with doses of AFOG for two weeks. The experimental animals were grouped in this manner:

Group 1: Control (vehicle- water).

Group 2: Plumbagin ${ }_{8 \mathrm{mg} / \mathrm{kg}}$.

Group 3: Plumbagin $8 \mathrm{mg} / \mathrm{kg}+\mathrm{AFOG}_{100 \mathrm{mg} / \mathrm{kg}}$

Group 4: Plumbagin $_{8 \mathrm{mg} / \mathrm{kg}}+\mathrm{AFOG}_{400 \mathrm{mg} / \mathrm{kg}}$

\section{Euthanization of Animals and Collection of Samples}

The animals were euthanized and sacrificed by cervical dislocation. Open castration method was used to excise the testes and epididymis. ${ }^{12}$

\section{Antioxidant level of the epididymis and testis}

These tissues were homogenized in 50mM Tris- $\mathrm{HCl}$ buffer ( $\mathrm{pH} 7.4$ ) having $1.15 \% \mathrm{KCl}$ and spinned using cold centrifuge for $15 \mathrm{~min}$ at $10,000 \mathrm{rpm}$ to obtain the post-mitochondrial fraction used for various assays. Catalase (CAT) activity was assayed at $240 \mathrm{~nm}$ using hydrogen peroxide as substrate according to the method of Claiborne. ${ }^{13}$ Superoxide dismutase (SOD) activity was evaluated as described by Misra and Fridovich. ${ }^{14}$ GSH level was estimated at $412 \mathrm{~nm}$ in accordance to Jollow et al. ${ }^{15}$ method. Percentage malondialdehyde (MDA) was assayed at $532 \mathrm{~nm}$ spectrophotometrically by following the protocol of Farombi et al. ${ }^{16}$

\section{Estimation of sperm motility}

This was carried out in compliance to Zemjanis' method. ${ }^{17}$ The sperm was obtained from the epididymis and diluted using $2.9 \%$ sodium citrate dihydrate solution at physiological temperature, gently admixed and overlaid with clean coverslip ( $24 \times 24 \mathrm{~mm}$ ). The motility was evaluated by considering not less than ten microscopic field at X200 magnification power. The sperm was categorized as either motile or immotile.

\section{Evaluation of epididymal sperm count}

It was determined as described by Rotruct method. ${ }^{18}$ The epididymis was homogenized in normal saline and sieved through nylon filter membrane. Exactly $0.1 \mathrm{ml}$ suspension was obtained by mixing $5 \mu \mathrm{l}$ sperm with $95 \mu \mathbf{l}$ diluent ( $0.35 \%$ formalin, $5 \% \mathrm{NaHCO}_{3}$ and $0.25 \%$ trypan blue). Precisely, $10 \mu \mathrm{l}$ of suspension was dispensed on Neubauer chamber and viewed under X400 magnification using light microscope.

\section{Estimation of sperm morphology and viability}

These were evaluated in accordance to the procedure of Habig. ${ }^{19}$ Smear of sperm suspension was made on hygienic glass slide and viability estimated by staining with eosin $(1 \%)$ and $5 \%$ nigrosine $3 \% \mathrm{C}_{6} \mathrm{H}_{5} \mathrm{Na}_{3} \mathrm{O}_{7}$. $2 \mathrm{H}_{2} \mathrm{O}$. Morphological aberrations were estimated by staining the smear dye that contains $0.1 \mathrm{~g}$ eosin and $0.3 \mathrm{~g}$ fast green solubilized in $\mathrm{dH}_{2} \mathrm{O}$ and $\mathrm{C}_{2} \mathrm{H}_{5} \mathrm{OH}(2: 1)$. Four hundred sperm cells were evaluated from each rat in order to determine the abnormalities.

\section{Circulatory concentrations of pituitary and testicular hormones assay}

These were determined using Elabscience assay kits by following manufacturer's instructions.

\section{Sperm plasma membrane integrity}

This was determined in rats using hypo-osmotic swelling test (HOST) as described by Turner and Lysiak. ${ }^{20}$ The solution $(150 \mathrm{mOsm} / \mathrm{L})$ was prepared by mixing $3.675 \mathrm{~g}$ sodium citrate with $6.755 \mathrm{~g}$ fructose in $500 \mathrm{ml}$ final volume using $\mathrm{dH}_{2} \mathrm{O}$. An aliquot of $100 \mu \mathrm{l}$ of sperm suspension obtained from cauda epididymis was made in $1000 \mu \mathbf{l}$ hypo-osmotic solution and incubated at $37^{\circ} \mathrm{C}$ for $60 \mathrm{~min}$. Exactly, 200 cells were counted for each sample from various fields at X400 magnification via light microscope and HOST positive sperms with twisted tail were evaluated.

\section{Histological procedures}

Testis samples were fixed with Bouin's solution for $24 \mathrm{hr}^{21}$ This is followed by dehydration of the tissues (via tissue processor-Leica TP 1020) by employing the use of ascending alcohol concentrations, then xylene was used to clear them and thereafter embedded in paraffin 
wax. ${ }^{22}$ About $4-5 \mu \mathrm{m}$ portions were excised via microtome, fixed on slides, stained with hematoxylin and eosin (H\&E) then viewed at $\mathrm{x} 400$ magnification under light microscope. The nuclei was stained blue and the cytoplasm pink.

\section{Statistical Analysis}

Data were analysed using One-way ANOVA and post hoc Dunnett's t-test through Graph pad prism 7 (La Jolla, California, USA). $P<0.05$ were reckoned significant.

\section{RESULTS}

\section{Aqueous fraction of Ocimum gratissimum leaf extract} improves the morphological parameters in the treatment groups

Table 1 shows the result of the sperm morphology in plumbagin-induced infertility in male wistar rats treated with aqueous fraction of Ocimum gratissimum leaf extracts for a period of two weeks. There was significant elevation $(P<0.05)$ in the sperm morphological status of the untreated group relative to control except for the total normal sperm which was significantly reduced. Similarly, significant differences $(P<0.05)$ were observed in all the sperm morphological parameters of treatment groups relative to control except for the total abnormal sperm with considerable decrease.

\section{Aqueous fraction of 0 . gratissimum leaf extract enhances sperm capacitation in the treatment groups}

Table 2 revealed that there was significant difference in the sperm capacitation of the untreated rats relative to control. Conversely, there was considerable improvement in the sperm capacitation of test groups with respect to control.

\section{Administration of aqueous fraction of $O$. gratissimum leaf extract prevents testicular membrane damage in Plumbagin-induced sterility in rats}

The results of sperm motility, viability and count together with membrane integrity in plumbagin-induced infertility in male Wistar rats treated with AFOG leaf extracts for a period of two weeks were revealed in Table 3. Dose-dependent increase was noticed in the sperm motility, viability, count and membrane integrity in the treated groups in comparison to control. Whereas, large difference $(P<0.05)$ was seen in these parameters in the untreated group relative to control.

\section{Circulatory hormones concentrations in sterile rats were} improved in the treatment groups by aqueous fraction of $O$. gratissimum leaf

There was drastic decline $(P<0.05)$ in serum testosterone and estradiol concentrations in the untreated group relative to control. Meanwhile, there is a dose-dependent increase in the treated groups relative to control (Figure 1).

\section{Oxidative stress was abrogated by treatment of sterile} rats with aqueous fraction of 0 . gratissimum leaf

Figure 2 shows the result of the antioxidant status (TAC, GSH, SOD, CAT) in the plumbagin-induced male Wistar rats treated with aqueous fraction of Ocimum gratissimum leaf extracts for a period of two weeks. There was considerable reduction $(P<0.05)$ in the untreated groups for all the parameters compared to control. Nonetheless, the antioxidant status was enhanced by rising doses in the treated groups relative to control.

Figure 3 revealed that there was considerable rise $(P<0.05)$ in the MDA level of untreated group relative to control. On the contrary, significant reduction $(P<0.05)$ was noticed in MDA status of treated groups relative to control.

\section{Aqueous fraction of $O$. gratissimum leaf repairs testicular} damage in sterile rats

Plate 1A showed that regular testicular architecture with normal seminiferous tubules and normal developmental phases of spermatozoa inside their lumen (white arrow) were observed. The spermatogonia and sertoli cells were standard. Also, normal leydig cells were seen in the interstitial spaces (slender arrow)

Plate 1B shows photomicrograph of a testicular section of plumbagininduced untreated group stained with $\mathrm{H} \& \mathrm{E}$ dye. There was mild leydig cell hyperplasia (black arrow) and maturation arrest in several seminiferous tubules (slender arrow)

Plate $1 \mathrm{C}$ and D show photomicrograph of a testicular section of 100 and $400 \mathrm{mg} / \mathrm{kg}$ AFOG treated groups stained using H\&E stain. Several normal seminiferous tubules with normal maturation stages and presence of spermatozoa within their lumen (white arrow) were observed. Few other seminiferous tubules with maturation arrest were also seen (black arrow). Leydig cells in the interstitial space were regular (slender arrow)

\section{DISCUSSION}

Consideration of male infertility is route to exonerating female counterpart as the solely culprit for inability to conceive and produce offspring by married couples. Researches have shown that male counterpart also contributes about $50 \%$ to this infertile condition. ${ }^{23}$ In response to this challenge, males are usually placed on drugs like clomiphene and anastrazole to boost sperm production. ${ }^{5}$ Sometimes, adverse reactions are observed with the use of these medications. Therefore, the use of natural compounds with little or no deleterious effect obtained from plants sources is desirable.

Ocimum gratissimum, also known as scent leaf, has been found to have various medicinal properties such as anti-oxidants, anti-bacterial, anti-

Table 1: Effect of aqueous fraction of 0 . gratissimum leaf extracts on sperm morphology in plumbagin-induced male Wistar rats.

\begin{tabular}{|c|c|c|c|c|c|}
\hline \multicolumn{6}{|c|}{ Morphology (\%) Distribution of Abnormalities } \\
\hline $\mathrm{NC}$ & $81 \pm 1.0$ & $19 \pm 0.5$ & $4.7 \pm 0.1$ & $3.7 \pm 0.01$ & $10.7 \pm 0.1$ \\
\hline $\mathrm{PG}+100_{\mathrm{mg} / \mathrm{kg}}$ AFOG & $77 \pm 2.5^{\mathrm{b}}$ & $21 \pm 1.2$ & $3.7 \pm 0.06^{\mathrm{ab}}$ & $3.0 \pm 0.07^{\mathrm{ab}}$ & $14.3 \pm 0.13^{\mathrm{a}}$ \\
\hline $\mathrm{PG}+400_{\mathrm{mg} / \mathrm{kg}}$ AFOG & $79 \pm 2.0^{\mathrm{b}}$ & $21 \pm 1.1$ & $2.3 \pm 0.04^{\mathrm{ab}}$ & $2.7 \pm 0.01^{\mathrm{ab}}$ & $14 \pm 0.11^{\mathrm{a}}$ \\
\hline
\end{tabular}

NC, Normal Control; PG, Plumbagin; PG $+100_{\mathrm{mg} / \mathrm{kg}}$ AFOG, Plumbagin + PG $+100 \mathrm{mg} / \mathrm{kg}$ Aqueous fraction of leave extract of Ocimum gratissimum; Plumbagin + PG $+400 \mathrm{mg} / \mathrm{kg}$ Aqueous fraction of leave extract of Ocimum gratissimum; Values are expressed as mean $\pm \mathrm{SD}(n=5)$; a: Test groups vs normal control $(p<0.05)$. b: Treatment groups vs Plumbagin alone $(p<0.05)$ 
Table 2: Effect of aqueous fraction of $O$. gratissimum leaf extracts on sperm capacitation in plumbagin-induced male Wistar rats.

$\begin{array}{cccc}\text { Groups } & \begin{array}{c}\text { Sperm Capacitation (\%) } \\ \text { Acrosome-intact } \\ \text { Uncapacited } \\ \text { Sperm }\end{array} & \begin{array}{c}\text { Acrosome- } \\ \text { intact } \\ \text { Capacitated } \\ \text { Sperm }\end{array} & \begin{array}{c}\text { Acrosome- } \\ \text { reacted } \\ \text { Capacitated } \\ \text { Sperm }\end{array} \\ \text { NC } & 2 \pm 0.01 & 1.5 \pm 0.01 & 96.5 \pm 1.1 \\ \text { PG } & 9.3 \pm 0.01^{\mathrm{a}} & 2.3 \pm 0.02^{\mathrm{a}} & 88.4 \pm 2.3^{\mathrm{a}} \\ \mathrm{PG}+100_{\mathrm{mg} / \mathrm{kg}} \text { AFOG } & 5 \pm 0.02^{\mathrm{ab}} & 5.3 \pm 0.01^{\mathrm{ab}} & 89.7 \pm 1.5^{\mathrm{ab}} \\ \mathrm{PG}+400_{\mathrm{mg} / \mathrm{kg}} \text { AFOG } & 2.3 \pm 0.1^{\mathrm{abc}} & 3.3 \pm 0.1^{\mathrm{abc}} & 94.3 \pm 1.3^{\mathrm{abc}}\end{array}$

NC, Normal Control; PG, Plumbagin; PG $+100_{\mathrm{mg} / \mathrm{kg}}$ AFOG, PG $+100 \mathrm{mg} / \mathrm{kg}$ Aqueous fraction of Ocimum gratissimum leaves extract; PG $+400 \mathrm{mg} / \mathrm{kg}$ Aqueous fraction of leaves extract of Ocimum gratissimum; Values are expressed as mean \pm SD $(n=5)$. a: Test vs normal control $(p<0.05)$. b: Treatment groups vs Plumbagin alone $(p<0.05)$. c: PG $+400_{\mathrm{mg} / \mathrm{kg}}$ AFOG vs PG $+100_{\mathrm{mg} / \mathrm{kg}}$ AFOG $(p<0.05)$.

Table 3: Effect of aqueous fraction of 0 . gratissimum leaf extracts on sperm parameters in plumbagin-induced male Wistar rats.

\begin{tabular}{ccccc} 
Groups & Motility (\%) & Viability (\%) & $\begin{array}{c}\text { Sperm } \\
\text { Count } \\
* 10 \wedge 6 \\
(\text { million }) / \mathrm{ml}\end{array}$ & $\begin{array}{c}\text { Host Sperm } \\
\text { Membrane } \\
\text { Integrity }\end{array}$ \\
NC & $92.5 \pm 1.1$ & $94.3 \pm 1.5$ & $39.3 \pm 0.5$ & $81.3 \pm 1.2$ \\
PG & $41.7 \pm 0.9^{\mathrm{a}}$ & $60 \pm 1.3^{\mathrm{a}}$ & $19.7 \pm 0.08^{\mathrm{a}}$ & $58.7 \pm 1.01^{\mathrm{a}}$ \\
$\mathrm{PG}+100_{\mathrm{mg} / \mathrm{kg}}$ & $88.3 \pm 2.3^{\mathrm{ab}}$ & $91.7 \pm 0.5^{\mathrm{ab}}$ & $25.7 \pm 0.83^{\mathrm{ab}}$ & $75 \pm 0.9^{\mathrm{ab}}$ \\
$\begin{array}{c}\text { AFOG } \\
\text { PG }+400_{\mathrm{mg} / \mathrm{kg}}\end{array}$ & $90 \pm 1.9^{\mathrm{ab}}$ & $95 \pm 0.9^{\mathrm{abc}}$ & $28.3 \pm 0.67^{\mathrm{abc}}$ & $79.3 \pm 1.32^{\mathrm{abc}}$ \\
AFOG & & & & \\
\hline
\end{tabular}

NC, Normal Control; PG, Plumbagin; PG $+100_{\mathrm{mg} / \mathrm{kg}}$ AFOG, PG $+100 \mathrm{mg} / \mathrm{kg}$ Aqueous fraction of Ocimum gratissimum leaves extract; PG $+400 \mathrm{mg} / \mathrm{kg}$ Aqueous fraction of leaves extract of Ocimum gratissimum; Values are expressed as mean $\pm \mathrm{SD}(n=5)$. a: Test vs normal control $(p<0.05)$. b: Treatment groups vs Plumbagin alone $(p<0.05) . c$ : PG $+400_{\mathrm{mg} / \mathrm{kg}}$ AFOG vs PG $+100_{\mathrm{mg} / \mathrm{kg}}$ AFOG $(p<0.05)$.
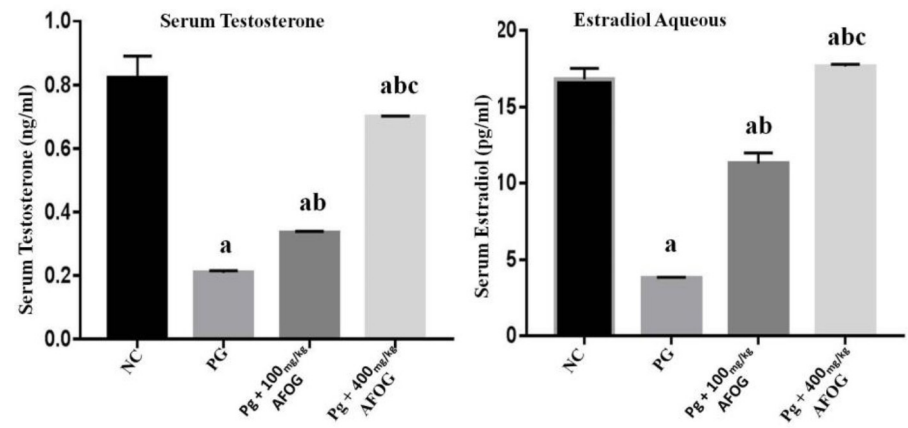

Figure 1: Effect of aqueous fraction of $O$. gratissimum leaf extracts on serum testosterone and estradiol aqueous in plumbagin-induced male Wistar rats. NC, Normal Control; PG, Plumbagin; PG $+100_{\mathrm{mg} / \mathrm{kg}}$ AFOG, PG $+100 \mathrm{mg} /$ $\mathrm{kg}$ Aqueous fraction of Ocimum gratissimum leaves extract; PG $+400 \mathrm{mg} /$ $\mathrm{kg}$ Aqueous fraction of leaves extract of Ocimum gratissimum. Values are expressed as mean \pm SD $(n=5)$ a: Test vs normal control $(p<0.05)$. b: Treatment groups vs Plumbagin alone $(p<0.05)$. c: PG $+400_{\mathrm{mg} / \mathrm{kg}}$ AFOG vs PG $+100_{\mathrm{mg} / \mathrm{kg}}$ AFOG $(p<0.05)$.

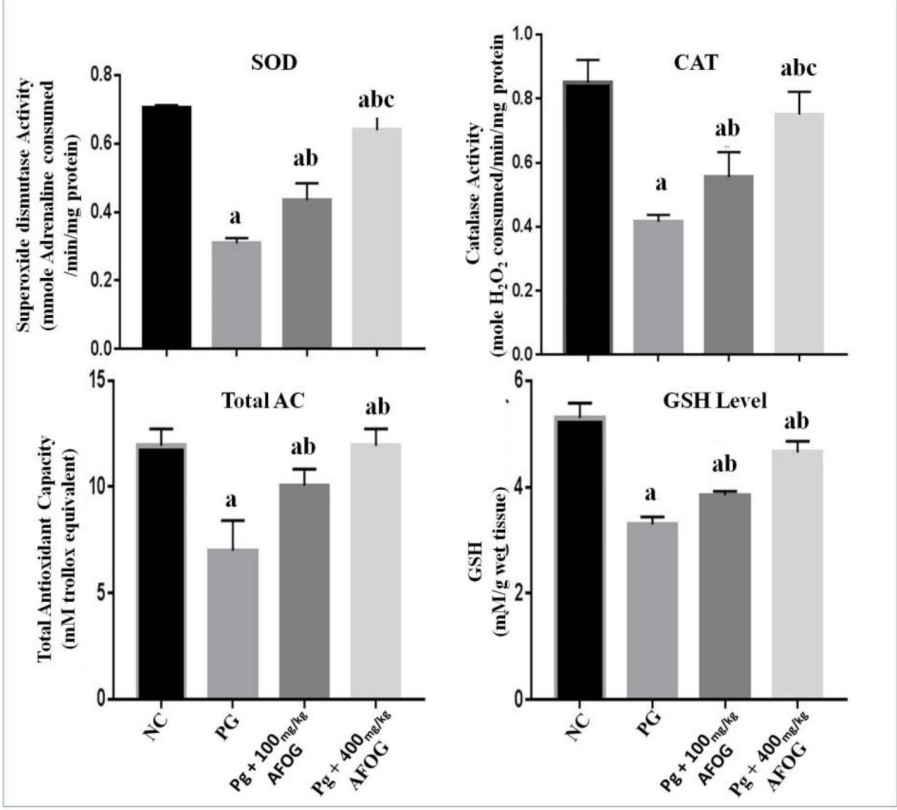

Figure 2: Effect of aqueous fraction of $O$. gratissimum leaf extracts on SOD activity, CAT activity, total antioxidant capacity and GSH levels in plumbagininduced male Wistar rats.

NC, Normal Control; PG, Plumbagin; PG $+100_{\text {mg/kg }}$ AFOG, PG $+100 \mathrm{mg} /$ $\mathrm{kg}$ Aqueous fraction of Ocimum gratissimum leaves extract; PG $+400 \mathrm{mg} /$ $\mathrm{kg}$ Aqueous fraction of leaves extract of Ocimum gratissimum; Values are expressed as mean $\pm \mathrm{SD}(n=5)$; a: Test vs normal control $(p<0.05)$. b: Treatment groups vs Plumbagin alone $(p<0.05)$. c: PG $+400_{\mathrm{mg} / \mathrm{kg}}$ AFOG vs PG $+100_{\mathrm{mg} / \mathrm{kg}}$ AFOG $(p<0.05)$.

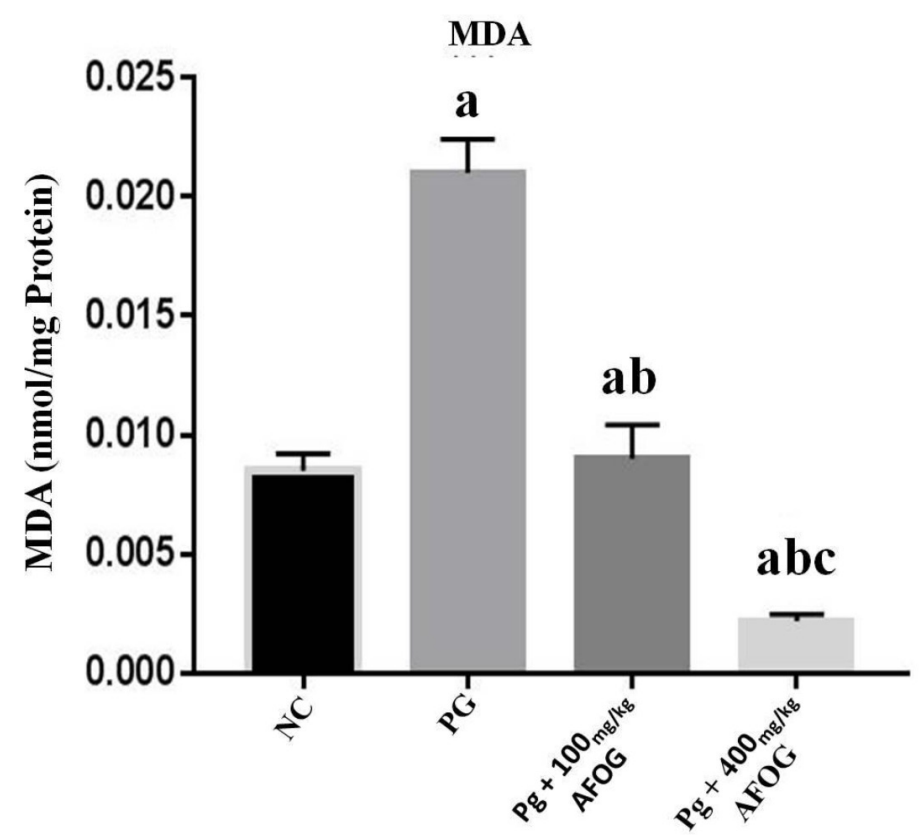

Figure 3: Effect of aqueous fraction of $O$. gratissimum leaf extracts on MDA level in plumbagin-induced male Wistar rats.

NC, Normal Control; PG, Plumbagin; PG $+100_{\text {mg/kg }}$ AFOG, PG $+100 \mathrm{mg} /$ $\mathrm{kg}$ aqueous fraction of Ocimum gratissimum leaves extract; PG $+400 \mathrm{mg} /$ $\mathrm{kg}$ aqueous fraction of leaves extract of Ocimum gratissimum. Values are expressed as mean $\pm S D(n=5)$. a: Test vs normal control $(p<0.05)$. b: Treatment groups vs Plumbagin alone $(p<0.05)$. c: PG $+400_{\mathrm{mg} / \mathrm{kg}}$ AFOG vs PG $+100_{\mathrm{mg} / \mathrm{kg}}$ AFOG $(p<0.05)$. 

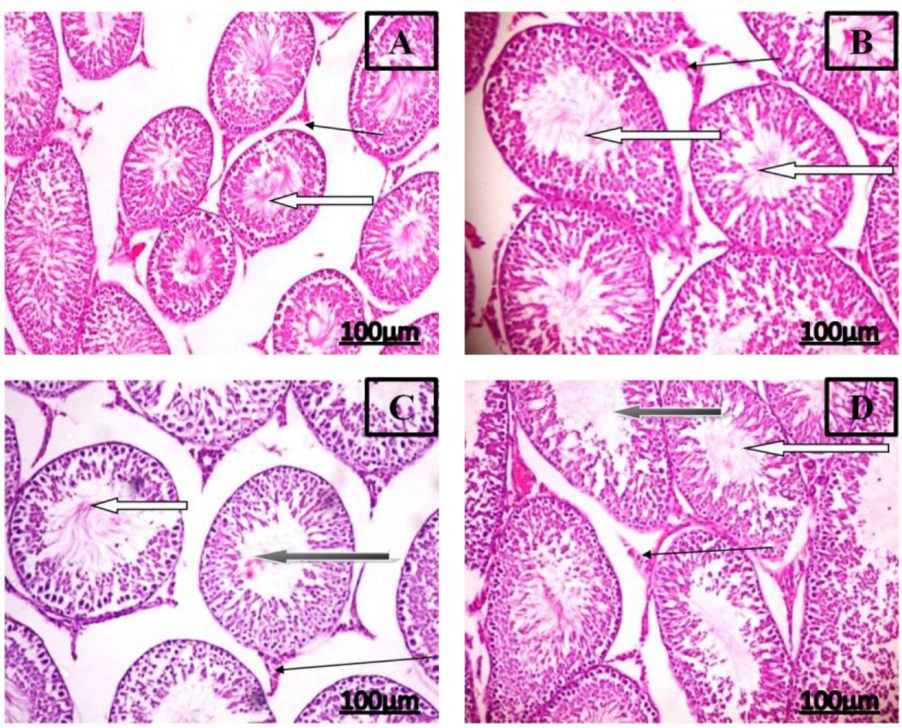

Plate 1: Representative testes histopathological sections of plumbagininduced testicular impairment in rats treated with AFOG.

A: Photomicrograph of testes of normal male Wistar rats $(\times 100)$. B: Photomicrograph of testes of infertile untreated male Wistar rats $(\times 100)$. C: Photomicrograph of testes of infertile male Wistar rats treated with $100 \mathrm{mg} / \mathrm{kg}$ aqueous fraction of Ocimum gratissimum leaf extract $(\times 100)$. D: Photomicrograph of testes of infertile male Wistar rats treated with $400 \mathrm{mg} / \mathrm{kg}$ aqueous fraction of Ocimum gratissimum leaf extract $(\times 100)$.

fungal, anti-diarrhoeal, anti-helmintic, anti-diabetic, anti-inflammatory, anti-nociceptive, anti-hypertensive, anti-convulsant activity. ${ }^{24}$

There was an increase in the body weight of the groups treated with doses of AFOG as opposed to the decline in the body weight in the untreated group. This may be due to the nutritional composition of AFOG in the groups as well as good appetite for chow and water.

The rise in serum testosterone level in the extract treated group could be that AFOG interacted directly with the testicular tissues, mopped-up oxidative radicals or even stabilized testes plasma membrane. Also, AFOG probably has a direct triggering activity on the Leydig cells thus, enhancing the synthesis of testosterone. However, a previous study revealed that crude aqueous extract of OG caused no significant effects on the serum levels of testosterone. ${ }^{25}$ AFOG exerted better effect as against crude aqueous extract, thereby showing that purification enhances activity.

Elevated estradiol level in the animals treated with doses of AFOG leaf revealed its anti-infertility potential. A previous study using Corchorus olitorius showed that there was decrease in the estrogen concentration which may stem from rats testes atrophy observed caused by severe reduction in the amount of adipose testicular tissues of the treated rats. ${ }^{26}$ The increase in the sperm viability observed on treatment of the Plumbagin-administered rats with doses of AFOG leaf extract may be due to the increase in the action of testosterone in fostering proper functioning of the epididymis, a site for sperm maturation. The improved spermatozoa motility could likely be through enhancement of membrane equilibrium which may be associated with the antioxidant efficacy of AFOG. This is consistent with the report that antioxidant helps to stabilize cell membrane. ${ }^{27}$

The increase in the sperm count shows that the Leydig and sertoli cells which are involved in the production of spermatozoa are not damaged. A previous study showed that there was a decrease in the sperm count due to direct damages to the Leydig and sertoli cells. ${ }^{25}$
High level of sperm capacitation in the treated groups depicts rising tendencies for fertilization to take place and this was corroborated by increase in the sperm count, motility and viability.

Considerable improvement in the sperm morphology observed upon administration of AFOG depicts that the plant extract in addition to its ameliorative role, does not contain components that could damage the cell membrane. This is supported by the report that Moringa oleifera extract administered to rats did not alter number of normal sperm count. Thus, denoting its non-toxic properties. ${ }^{28}$

Catalase is an enzyme that plays vital role in the degradation of hydrogen peroxide into water and oxygen. ${ }^{29}$ The increased catalase activity in the groups treated with AFOG as obtained in the results shows their antioxidant efficacy. Other antioxidant indices were equally enhanced. These enzymes assist in scavenging free radicals from the biological system. It could be suggested that phytoconstituents in AFOG acted to either boost the antioxidants reserve in the body or directly scavenged the free radicals from the system. It was reported that phytochemicals in Ocimum gratissimum have antioxidant potentials which are responsible for its free radical scavenging activity and protection against oxidative stress-induced morphological change and cellular damage in several systems. ${ }^{30}$

Elevated levels of MDA in the testis has been shown to cause high oxidative stress which can damage the sperm cells and cause fertilization problems. ${ }^{31}$ This causes cell death through membrane lipid peroxidation which has been implicated in DNA damage and precipitation of different disease conditions. ${ }^{32}$ In contrast, this study reveals reduction in the MDA level of rats administered AFOG, thereby showing its ability to inhibit cell damage. This could be adduced to the phytochemicals present in the AFOG.

The histopathology of the testes shows that there was ameliorative impact of AFOG on plumbagin-triggered testicular impairment in treated rats as normal testicular architecture, normal seminiferous tubules with few abnormal ones and normal maturation were observed.

Severe testicular injury seen in untreated group revealed that plumbagin is capable of causing alteration in seminal parameters. This is in tandem with the report of Bello ${ }^{12}$ that Plumbagin exhibited destructive effect on testicular organs, thus causing infertility. However, this damage was significantly repaired via treatment with AFOG, thereby showing it as promising phytotherapeutic agent for management of testicular insult. In contrast, this is opposed to the report of Orieke et al..$^{26}$ that demonstrated crude aqueous extract of $O$. gratissimum to cause damage to the seminiferous epithelium, characterized by varying degrees of edema within the tubules and the interstitial cells, reduced spermatogenesis and collapse of the tubules under the tunica albunigea.

\section{CONCLUSION}

It could be inferred from this study that AFOG leaf possesses bioactive compounds which exhibited cytoprotective role against testicular injury and thus, may be a promising phytotherapeutic agent for treating infertility in male.

\section{CONFLICT OF INTEREST}

The authors declare that there is no conflict of interest.

\section{REFERENCES}

\footnotetext{
1. Okonko LE, Ikpeme EV, Kalu SE. Sperm Profile and Testicular Weight Assessment of Albino Rats Administered African Nutmeg (Monodora myristica) and African Basil (Ocimum gratissimum). Asian J Biol Sci. 2019;12(3):477-81. doi: 10.3923/ajbs.2019.477.481.
}

2. Agbodjento E, Klotoé JR, Sacramento TI, Dougnon $V$, Tchabi FL, Déguénon E, 
Atègbo J. Ethnobotanical knowledge of medicinal plants used in the treatment of male infertility in southern Benin. ADV TRADIT MED (ADTM). 2021;21(4):655-73. doi: 10.1007/s13596-020-00473-3

3. Abdelgader A, Elsheikh A. Antiandrogenic activity of Calotropis procera latex in rats. Asian Pac J Reprod. 2018;7(3):4-9. doi: 10.4103/2305-0500.233574.

4. Adedara IA, Abolaji AO, Ladipo EO, Fatunmibi OJ, Abajingin AO, Farombi EO. 4-Vinylcyclohexene diepoxide distrupts sperm characteristics, endocrine balance and redox status in testes and epididymis of rats. Chem Biol Interact. 2017. doi: 10.1016/j.cbi.2016.12.09.

5. Slowiczek L, Sissons C. Does clomid work for male infertility? Medica News Today 2019.

6. Adeogun O. Adekunle A and Ashafa A. Chemical composition, lethality and antifungal activities of the extracts of leaf of Thaumatococcus daniell against foodborne fungi. Beni Suef Univ J Basic Appl Sci. 2016;5:356-68.

7. Ikpeme EV, Okonko LE, Udensi OU. Detrimental effects of chlorpyrifos and cypermethrin on reproductive physiology of male albino rats. Res $\mathrm{J}$ Environ Toxicol. 2016;10(1):68-74. doi: 10.3923/rjet.2016.68.74.

8. Shittu ST, Shittu SA, Olatunji AA, Oyeyemi WA. Ocimum gratissimum leaf extract may precipitate infertility in male diabetic Wistar rats. JBRA Assist Reprod. 2019;23(1):34-44. doi: 10.5935/1518-0557.20180072, PMID 30376279.

9. Oluwasola O, Maroyi A, Jide Afola A. Effects of Leaf Extracts of Ocimum gratissimum L. on Quality of Fresh Cut Cucumis sativus L. Asian J Plant Pathol. 2017;11(4):174-84. doi: 10.3923/ajppaj.2017.174.184.

10. Ebong P. Combined therapy of Moringa oleifera and Ocimum gratissimum reversed testicular damage in diabetic rats. Br J Med Med Res. 2014;4(11):2277-90. doi: 10.9734/BJMMR/2014/7078

11. Bello IJ. Modulation of mitochondrial-mediated cell death by Plumbagin in rats [PhD thesis]. Nigeria: Department of Biochemistry, University of Ibadan; 2021.

12. Kandeel FR, Koussa VKT, Swerdloff RS. Male sexual function and its disorders: Physiology, pathophysiology, clinical investigation, and treatment. Endocr Rev. 2001;22(3):342-88. doi: 10.1210/edrv.22.3.0430, PMID 11399748.

13. Clairborne A. catalase activity. In: Greewald AR, editor. Handbook of methods for oxygen radical research. Boca Raton: CRC Press Press; 1995. p. 237-42.

14. Misra HP, Fridovich I. The role of superoxide anion in the autoxidation of epinephrine and a simple assay for superoxide dismutase. J Biol Chem. 1972;247(10):3170-5. doi: 10.1016/S0021-9258(19)45228-9, PMID 4623845.

15. Jollow DJ, Mitchell JR, Zampaglione N, Gillette JR. Bromobenzene-induced liver necrosis. Protective role of glutathione and evidence for 3,4-bromobenzene oxide as the hepatotoxic metabolite. Pharmacology. 1974;11(3):151-69. doi: 10.1159/000136485, PMID 4831804.

16. Farombi EO, Tahnteng JG, Agboola AO, Nwankwo JO, Emerole GO. Chemoprevention of 2-acetylaminofluorene-induced hepatotoxicity and lipid peroxidation in rats by kolaviron - a Garcinia kola seed extract. Food Chem Toxicol. 2000;38(6):535-41. doi: 10.1016/s0278-6915(00)00039-9, PMID 10828505

17. Zemjanis R. Collection and evaluation of semen. In: Zemjanis R, editor. Diagnostic and therapeutic technique in animal reproduction. 2nd ed. Baltimore: William and Wilkins Comapny. Wvalerly Press, Inc; 1970. p. 139-53.
18. Rotruck JT, Pope AL, Ganther HE, Swanson AB, Hafeman DG, Hoekstra WG. Selenium: Biochemical role as a component of glutathione peroxidase. Science. 1973;179(4073):588-90. doi: 10.1126/science.179.4073.588, PMID 4686466.

19. Habig WH, Pabst MJ, Jakoby WB. Glutathione S-transferases. The first enzymatic step in mercapturic acid formation. J Biol Chem. 1974;249(22):7130-9. doi: 10.1016/S0021-9258(19)42083-8, PMID 4436300.

20. TurnerTT, Lysiak JJ. Oxidative stress: A common factor in testicular dysfunction. J Androl. 2008;29(5):488-98. doi: 10.2164/jandrol.108.005132, PMID 18567643.

21. Avwioro OG. Histochemistry and tissue pathology-principles and techniques. 1st ed. Ibadan, Nigeria: Claverianum Centre; 2002. p. 155-7, 214-8.

22. Yoshida S, Hiyoshi K, Ichinose T, Takano H, Oshio S, Sugawara I, et al. Effect of nanoparticles on the male reproductive system of mice. Int $\mathrm{J}$ Androl. 2009;32(4):337-42. doi: 10.1111/j.1365-2605.2007.00865.x, PMID 18217983.

23. Winters BR, Walsh TJ. The epidemiology of male infertility. Urol Clin North Am. 2014;41(1):195-204. doi: 10.1016/j.ucl.2013.08.006, PMID 24286777.

24. Imosemi 10. A review of the medicinal values, pharmacological actions, morphological effects and toxicity of Ocimum gratissimum Linn. Eur J Pharm Med Res. 2020;7(7):29-40.

25. Obianime AW, Aprioku JS, Esomonu CTO. Antifertility effects of crude aqueous extract of Ocimum gratissimum leaves in male mice. J Med Plants Res. 2010;4:809-16.

26. Orieke D, Ohaeri OC, Irene ljeh II, ljioma SN. Semen quality, hormone profile and histological changes in male albino rats treated with Corchorus olitorius leaf extract. Avicenna J Phytomed. 2019;9(6):551-62. doi: 10.22038/AJP.2019.13426, PMID 31763214.

27. Njan AA, Olaoye SO, Afolabi SO, Ejimkonye BC, Soje A, Olorundare OE, et al. Safety effect of fractions from methanolic leaf extract of Ocimum gratissimum on reproduction in male Wistar rats. Toxicol Rep. 2019;6:496-504. doi: 10.1016/j. toxrep.2019.04.009, PMID 31205861.

28. Obembe OO, Raji Y. Effects of aqueous extract of Moringa oleifera seed on cadmium-induced reproductive toxicity in male Wistar rats. Afr Health Sci. 2018;18(3):653-63. doi: 10.4314/ahs.v18i3.23, PMID 30602998.

29. Tadayuki I, AkikoT, Shinya S, Ken-ichi O, Ippei H, Yuko K, et al. A simple assay for measuring catalase activity: A visual approach. Sci Res. 2013;3:3081.

30. Akinmoladun CA, Emmanuel I, Emmanuel A, Efere MO, Farombi EO. Phytochemical constituent and oxidant activity of extract from the leaves of Ocimum gratissimum Sci Res Essays. 2007;2:163-6.

31. Aprioku JS. Pharmacology of free radicals and the impact of reactive oxygen species on the testis. J Reprod Infertil. 2013;14(4):158-72. PMID 24551570.

32. Ochsendorf FR, Ozdemir K, Rabenau H, Fenner T, Doer HW. Journal of the European Academy of Dermatology and Venerology, 1999;12:143-52.

Cite this article: Salemcity AJ, Agbaje TS, Effiong ME, Asuelimen SO. Aqueous Fraction of Ocimum gratissimum (L) Leaf Extract Protects Sperm Membrane Integrity in Plumbagin-induced Testicular Damage in Rats. Free Radicals and Antioxidants. 2021;11(2):52-7. 